\title{
Liberdade, identidade e criatividade na Música Popular Uruguaia ${ }^{1}$
}

Josseline I. Cabanne

Instituto Uruguayo de Educación por el Arte: Taller Barradas. Centro de Investigación y Experimentación Pedagógica - CIEP.

E-mail: jobearn@yahoo.com

Resumo: A autora aborda o período ditatorial do Uruguai, de 1973 a 1985, e demonstra como a censura, mesmo tentando silenciar as produções simbólicas, os poemas, as vozes e os cantos, não impediu o aparecimento de numerosos poetas e artistas que, retomando o caminho precursor de Bartolomé Hidalgo, poeta uruguaio (1788-1822), registravam, oficiando de lúcida memória, os processos históricos e culturais que aconteciam no Uruguai. Sob condições bastante severas, fez-se presente a liberdade criadora da maioria dos músicos como compromisso político de contrapeso a uma das piores ditaduras da América Latina, na qual, quase em uníssono, se dá a coincidência dos regimes na Argentina, Brasil, Chile e Paraguai. Ela destaca dois expoentes que, no seu entender, sintetizam o exercício mais alto da liberdade criativa na segunda metade do século XX: Alfredo Zitarrosa e Eduardo Mateo.

Palavras-chave: censura, história, música, canto popular, cultura.

\begin{abstract}
The author tackles dictatorial period in Uruguay (1973-1985) and shows how censorship did not manage to stop the coming out of numerous poets and artists who, following the precursor way of the Uruguayan poet Bartolomé Hidalgo (17881822), registered the historical and cultural processes that happened in Uruguay. Under extremely severe conditions, the creative freedom of most musitians made itself present as a political commitment to counterbalance one of the worst dictatorships in Latin America, that, almost in unison, also happened in Argentina, Brazil, Chile and Paraguay. She highlights two exponents that, in her understading, synthesize the highest exercise of creative freedom in the second half of the 20th century: Alfredo Zitarrosa and Eduardo Mateo.
\end{abstract}

Keywords: censorship, History, music, popular singing, culture

"Céu, cielito que sim" são palavras que originam um estilo e aparecem na obra de Bartolomé Hidalgo (poeta uruguaio, 1788-1822), um dos precursores de uma poesia engajada, corajosa, na qual se refletem as lutas de sua época, marcada por invasões e luta pela independência. Ele é protagonista e testemunho lúcido que marca um rumo criador e identitário, o qual lança raízes profundas em sua terra, inaugurando com seus cielitos um espaço para a liberdade criadora.

No Uruguai, pelo qual tanto lutou Hidalgo, e situando-nos no período de 1973 a 1985, em um sufocante ambiente criado pela ditadura, que exerceu

Recebido: 13/4/2008

Aprovado: 9/5/2008

1. Trabalho apresentado no Segundo Congreso Internacional Escrituras Silenciadas: Historia, Memoria Y Procesos Culturales. Universidad de Alcalá. Alcalá de Henares, 11 de Diciembre de 2007. Madrid, Espanha. 
comunicação \& educação • Ano XIII • Número 3 • set/dez 2008

- entre outras atrocidades - uma forte censura, tentando silenciar as produções simbólicas, os poemas, as vozes e os cantos, surgiram numerosíssimos poetas e artistas que, retomando o caminho precursor de Hidalgo, registravam, oficiando de lúcida memória, os processos históricos e culturais que aconteciam no Uruguai. Sua criação atuou como bastião cultural, originando um numeroso e contestador movimento que imprimiu uma marca muito especial durante os anos da feroz ditadura que o país sofreu.

\section{CLIMA SOCIAL DOS ANOS 1973 A 1985}

Ao levar-se em conta a população total do Uruguai - que na década de 1970 não chegava a três milhões de habitantes -, esses artistas formaram um numeroso e efervescente movimento que imprimiu uma marca muito especial ao longo da ditadura.

Nesses anos, a ditadura exerceu um total domínio político, educativo e cultural, e em outras esferas do tecido social. Apesar disso, e sob condições bastante severas, burlando a censura, em um exercício para o qual se uniram a criatividade e a luta, e quando todas as condições externas eram adversas, se fez presente a liberdade criadora.

Ante os primeiros indícios repressivos que logo se consolidaram no regime autoritário militar, surgiu uma resposta criativa que implicou, para a maioria dos músicos, um compromisso político de contrapeso a uma das piores ditaduras de nossa América. América na qual, quase em uníssono, se deu a triste e feroz coincidência das ditaduras na Argentina, no Brasil e no Chile, bem como permanecia a do Paraguai; e aqui, no Uruguai, vivia-se o período mais tenebroso de nossa história.

O regime militar, exercendo forte controle sobre os meios de comunicação de massa (que de fato apoiaram a ditadura divulgando canções como Disculpe [Desculpe], a qual os artistas do Canto Popular responderam com a música Está disculpado [Está desculpado] e outras de conteúdo similar), começou a perseguir e investir, com as porquinhas azuis (com suas sirenes uivantes), contra autores e músicos, lotando os presídios com vários deles e obrigando a muitos um exílio forçado. Em contrapartida, houve um apoio quase geral da esquerda - assim como de boa parte do povo -, uma compreensão e uma atitude de reconhecimento do Canto Popular, um lúcido e brilhante espelho que refletia sua identidade, como contrapeso, pois surge um povo que contesta com sua escuta alerta e atenta às manifestações sonoras da mais alta música popular, elaborando juntos, autores e público - o qual vai paulatinamente aguçando sua sensibilidade -, uma criadora, cúmplice e sonora oposição aos tenebrosos sons do autoritarismo.

Ante um tema que tanto machuca boa parte dos uruguaios, procurei aproximar-me com certa dose de respeito e reconhecimento (o que me demandou uma pesquisa de informação em diversas leituras sobre o tema). Nutrida com a informação recolhida, e acompanhada da audição dos discos que permitiram o 
ressurgimento sonoro daquela época, foi crescendo em mim a admiração pelo trabalho criador de muitos artistas da Música Popular Uruguaia.

De seus vários cultivadores, selecionei dois expoentes que, no meu entender, sintetizam o exercício mais alto da liberdade criativa na segunda metade do século XX. Refiro-me a Alfredo Zitarrosa e Eduardo Mateo, ambos - em distintos estilos - atualmente considerados, em pleno século XXI, pertencentes à Música Popular Uruguaia.

\section{ALGUNS ANTECEDENTES DA MÚSICA EM NOSSO TERRITÓRIO}

Se nos situarmos no território uruguaio e desejarmos rastrear uma música que nos represente, na qual nos reconheçamos e que nos confira identidade, seria oportuno estender nosso olhar - ou mais precisamente nosso ouvido - para o mais distante arco musical de Tacuabé, que também cita, entre outros, Pero López de Souza, o qual, em seu Diário de Navegantes, conta que, no dia 25 de outubro de 1531, desembarcaram seus homens no porto da praia de Maldonado, onde "os [índios] charrúas os receberam com grandes choros e cantigas muito tristes" ${ }^{\prime 2}$. Mas hoje nem todos os que habitam esta terra desejam recuperar esta memória sonora, optando pela solução provocada pela barbárie de Salsipuedes, que deixou no esquecimento e privou-nos da contribuição musical indígena no Uruguai.

Se estendermos nosso ouvido a um passado mais remoto, como foi o da época da Conquista, é interessante resgatar a opinião autorizada do músico Rubén Olivera, que em seu excelente e esclarecedor trabalho, A música como linguagem de dominação (Semanario Brecha, 19 de fevereiro de 1988), e falando especificamente do tema político, nos diz:

Fizeram-se estudos sobre como os povos mudam sua emissão de voz a partir da época da Conquista. Os astecas e em geral as comunidades centro-americanas tinham um emissão totalmente diafragmática, abdominal. A partir da Conquista começa a se elevar a colocação e a altura da emissão, tornando-se mais aguda ("no tiene una monedita, padrecito" ["não tem uma moedinha, senhorzinho"]. Os espanhóis proibiam que se tocassem instrumentos ou os destruíam para eliminar os elementos de unidade. Em determinado momento, começam a desaparecer músicos na Europa, cujo rastro perde-se nos arquivos europeus. Por sua vez, começam a aparecer em nosso continente pessoas com o mesmo nome que se dedicam à tarefa evangelizadora e ao ensino de determinado tipo de música (piano, cantos eclesiásticos). Tal é o caso de Doménico Zipoli, jesuíta.

O fragmento anterior é um ilustrativo exemplo de voz, música e linguagem silenciados sob o poder evangelizador e globalizador que exerceu a Companhia de Jesus - com sede central em Roma. Pode parecer pouco, mas se aquietou e se transformou - ao se exercer esse poder totalizador - a voz dos vencidos, vozes, linguagens, músicas, instrumentos que eram portadores de uma cultura e de uma complexa identidade de riquíssima tradição em nossa América indígena.

2. BALZO, H. La vida musical (A vida musical) Montevideo: Uruguay, 1969. p. 83. 


\section{O PERICOM}

Com o tempo, vão surgindo formas musicais que apontam para a consolidação da identidade nacional. No fim do século XIX, encontramos uma publicação - Diario del Uruguay, com a seguinte manchete: $O$ Pericom não é mais uma extravagância. E desdobrava na seqüência da notícia: "No dia 3 de agosto de 1887, tocará na Escola da Banda de Artes e Ofícios o Pericom Nacional, que já tocava e dançava em alguns salões da capital e em vários lugares do interior", incorporando assim essa música à memória coletiva.

\section{CIFRA E PAYADA}

$\mathrm{Na}$ região, mais especificamente nas zonas rurais da Argentina e do Uruguai, cultivou-se um gênero musical, a payada. Leiamos o que opina Lauro Ayestarán:

A cifra traz consigo duas das características mais destacadas do cancioneiro uruguaio: sua condição melódica eminentemente silábica e seu caráter fortemente individualista. Não existe, em todo nosso repertório lírico, uma só modalidade que seja cantada coletivamente em coro, nem mesmo em reduzidas combinações vocais, e quando a cifra, que serve para a "payada de contraponto", é cantada entre dois paisanos - é a única modalidade vocal na qual pode participar mais de uma pessoa -, o fazem de modo alternado e para discutir em verso cantado; ou seja, para sublinhar ainda mais essa marca individual que é a expressão mais profunda do nosso cancioneiro ${ }^{3}$.

\section{TANGO}

Na segunda metade do século XIX, nasce, no Rio da Prata, em suas duas principais cidades, uma música, o tango, que, conforme afirma Daniel Vidart:

O tango, "nosso tango" que não é tão nosso como se crê, teve uma origem elusiva e despistadora: a casca e a semente, o referente e a referência se confundiram, por caminharem juntos a palavra com seus significados. Por um lado, as velhas raízes hispânicas revelam que o tango, talvez nascido em Andaluzia, esse milenar manancial de povos e culturas, aclimatava-se na Ilha de Hierro, uma das Ilhas Canárias, por volta de 1840, antes de "trepar-se nas zarzuelas madrilenhas". Por outro lado, os tangos e os tambos dos negros, considerados escandalosos pelos documentos coloniais, não constituíam um gênero musical: designavam os antepassados dos tamborins, esses membranófonos que presidem as "chamadas" dos afro-uruguaios. O tango criollo ganha vida no Rio da Prata a partir de uma mistura de habaneras e milongas, ambas de ascendência hispânica, com os tangos zarzueleiros, e conhece três etapas, que, longe de se anularem reciprocamente, se somam e se complementam. São elas, a dança, as letras escritas por autor conhecido para ser cantadas e a etapa da música enquanto exercício de aperfeiçoamento artístico e orquestral [...]. Nosso tango criollo, nos anos oitenta do

3. Disponivel em: <http:// letras-uruguay.espaciolatino.com/ayestaran/la_cifra.htm>. século XIX, define nas academias, terror de suas cidades-matrizes - Montevidéu, Buenos Aires e Rosário de Santa Fé, segundo uma comprovada ordem de priori- 
dades -, as células rítmicas de uma dança que logo se transformará no manifesto coreográfico da conjunção de dois mundos ${ }^{4}$.

Diversos autores fazem um trabalho de pesquisa que tende a trazer um elo a mais à cadeia de resgate de nossa identidade. Seguindo a linha inaugurada sobre o tema por Daniel Vidart, analisam o tema da cotidianeidade da cultura popular urbana entre os anos de 1860 e 1900, em uma época de profundas transformações sociais e políticas em nosso país e:

[...] quando grande quantidade de indivíduos provenientes do meio rural, expulsos pelo arame farpado dos campos e pelas políticas de "modernização rural" promovidas pela ditadura do Coronel Latorre (e seus sequazes Santos e Tajes), vai em busca de um destino em Montevidéu; e quando as embarcações chegam a nosso porto, enormes contingentes de europeus humildes, provenientes também em sua maioria dos meios rurais, encontram-se aqui com uma importante população negra e mulata - de enorme concentração nas regiões em que eles vão viver -, com produtos e práticas culturais próprias, dentre as quais se encontram algumas músico-coreográficas, reconhecidas comumente pela sociedade pelos nomes de Habanera, Tango e Candombe 5 .

E na primeira parte do século XX, localizados no território do popular por antonomásia, está a figura de Carlos Gardel, marcando fortemente com seu estilo, com sua voz, com seu canto, as bases da identidade nacional.

Aqui daremos um salto no tempo, recordando que, em 2007, se completaram 90 anos de La Cumparsita - uruguaio, mas pedido em empréstimo sem devolução pelos argentinos, que, no dizer de Vidart, "tão argentino é, ou pretende ser, que La Cumparsita, um tango montevideano até o último fio de cabelo, viajou por todo o mundo como o máximo expoente do portenhismo musical”.

\section{CONTRIBUIÇÕES DA MÚSICA CULTA}

Já em pleno século XX e sob a ótica da música culta, ao escutar Eduardo Fabini com seu Campo, nós o incorporamos a esta memória, reconhecendo-o como próprio (é interessante o fato de a mãe de Eduardo Mateo, admiradora de Fabini, ter dado este nome ao filho em homenagem ao compositor, e talvez as honras que rende Mateo em sua obra, na sua maneira de "viver" tão criativamente esse nome, estejam realizando o sonho de sua mãe de "ser músico" como Dom Eduardo).

Esses antecedentes musicais deixaram uma marca, povoando a memória sonora dos uruguaios de cielitos, payadas, pericomes, zarzuelas, habaneras, milongas, tangos e candombes, os quais se somaram à música que cada qual escutou na infância, nas vozes familiares de avós e mães, repetindo antigas canções de tradição oral; todas elas foram assimiladas em menor ou maior medida, unindo-se em alguns casos às vertentes da música clássica e criando um universo sonoro cuja produção, nos anos mais duros da ditadura, ofereceu um bastião de resistência cultural.

4. VIDART, D. La trama de la identidad nacional (A trama da identidade nacional). Montevideo: Uruguay, 1997. p. 111.

5. WEROSCH, Sheila y VENEZIANI, W. Abran cancha, acá baila un oriental (Abram caminho, aqui está dançando um uruguaio). Montevideo: Uruguay, 2006. p. 53-54. 6. VIDART, op. cit., p. 108. 
comunicação \& educação • Ano XIII • Número 3 • set/dez 2008

\section{MÚSICA POPULAR URUGUAIA/CANTO POPULAR}

Para propiciar uma aproximação ao tema, optei por ir às fontes, efetuando um percurso pelas opiniões mais autorizadas, como são as citadas a seguir: Coriún Aharonián, Guilherme de Alencar Pinto, Washington Benavídez, Roy Berocay, Jorge Bonaldi, Eduardo Darnauchans, Carlos Muñoz e Rubén Castillo, Carlos A. Martins, além de Eduardo Mateo e Alfredo Zitarrosa.

Ao ler uma apresentação de Coriún Aharonián, encontramos:

Enquanto a Revolução Cubana não conseguia resolver a problemática de uma cultura popular para a nova sociedade (e o desejado "homem novo"), a canção popular se desenvolveu no Uruguai com uma forte criatividade na segunda metade dos anos sessenta e na primeira metade dos setenta. A feroz ditadura ultrafascista considerou a canção popular especialmente perigosa e tentou calála de muitas maneiras. Houve proibições, pressões, torturas, exílios, repressão violenta da mera audição de uma canção em domicílio privado. $\mathrm{O}$ silêncio foi preenchido por novos jovens. Os mais críticos em relação ao triunfalismo de seus irmãos mais velhos desenvolveram uma nova etapa, que conseguiu, mesmo nos tempos mais duros, estabelecer contramodelos musicais que chegaram com freqüência a ser massivamente aceitos. E aqui aparece outro fato curioso: esses contramodelos historicamente condenados ao gueto e cercados permanentemente pelas armadilhas dos serviços de inteligência, não só conseguiam saltar as inumeráveis valas e transformar-se no fato político por excelência da resistência ao regime ditatorial, como também, além disso, conseguiram enfrentar, de uma maneira ou de outra, a força arrasadora do martelo dos grandes centros de poder (e o pequeno martelar do tradicionalismo retrógrado da mentalidade do poder imediato). Acontecia mais uma vez o triunfo dos músicos populares sobre as impossibilidades intermináveis?

Segundo De Alencar Pinto:

Uma boa data simbólica para o início do Canto Popular seria a quinta-feira, 24 de março de 1977, estréia de Os que iam cantando no Café Concert Shakespeare \& Co. de Pocitos. A música uruguaia tomou um rumo novo e teve início um fenômeno absolutamente singular. [...] Sombras... A ditadura censurou, proibiu e/ou exilou as principais figuras da canção de protesto e minou as bases econômicas do candombe-beat. Isso não explica totalmente a sensação de deserto imperante entre 1973 e 1977. A música uruguaia possui características bastante exclusivas, muito particulares; um exemplo dessas peculiaridades pode estar no mal chamado movimento folclorista dos anos 60 , e que põe como exemplo de precursores Zitarrosa, Viglietti, Los Olimareños (que inauguram uma modalidade de duo no Uruguai). Há vários fatores que favoreceram a qualidade, variedade e quantidade da música popular uruguaia a partir da década de 1960:

1) ampla classe média;

2) alto grau de educação e urbanização;

3) relativo bem-estar (recurso e disponibilidade de lazer);

4) fácil absorção de informação dos centros de poder;

5) tradições musicais próprias, geradoras de perfis característicos;

6) equilíbrio ante as gravitações de Argentina e Brasil; tudo da música popular 1997 
7) um mercado com a justa medida que permitia e fomentava o desenvolvimento das carreiras dos músicos, apesar de não gerar ganhos suficientes para criar as condições de uma "música comercial";

8) forte espírito crítico atiçado pelo conflituoso contexto político ${ }^{8}$.

Bonaldi coincide com De Alencar Pinto em situar o início do Canto Popular no ano de 1977, e em considerá-lo como o ano do ressurgimento da canção popular, a qual define assim:

[...] a canção popular de interpretação ou canto popular, como é também chamada, ostenta no Uruguai uma longa trajetória que remonta, talvez, aos tempos da luta independentista contra o poder colonial (século 19) e está baseada no costume de descrever, mediante o canto, as diferentes facetas da vida e epopéia do povo. Assim vão sendo narradas vivências coletivas e individuais, mas geralmente ligadas ao sentir coletivo, através de um tipo de canção em muitos casos evolutiva, de base artística e criativa, e que conta em todos os casos com um profundo sentimento humanista e solidário. Isso atestam os cantores populares, que é possível ver hoje mesmo, correndo o mundo, exilados ${ }^{9}$.

Para Washington Benavídez:

O Canto Popular Uruguaio corresponde ao "Novo Canto", ou à "Nova Canção" ou à "Nova Trova", ou à "Canção de texto", que surgem na América Latina e na Espanha na efervescente década de sententa. Os propósitos comuns que encontramos entre os "trovadores", "cantores de texto" e "cantores populares uruguaios”, seriam, entre outros aspectos regionais e muito próprios, os seguintes: rigor criativo, tanto na expressão musical como nas letras; abertura necessária (contando com as necessárias raízes do folclore, original ou torrencial) às formulações de uma música que, por sua extrema difusão, transforma-se em um "fundo universal de comunicação". Em nosso país, o "Canto Popular" engloba formulações bem diversas, e que, de uma vez por todas, carecem de definição. O Canto Popular Uruguaio na primeira geração (a dos anos sessenta) apresenta já distintas vertentes: a de raiz folclórica (Zitarrosa, Carbajal etc.) ou camponesa (os mesmos nomes e alguns mais); a urbana (com candombe, rock, jazz, milonga) com o Kinto, o grupo del Plata, Manolo Guardia e seu conjunto, e solistas que desenvolveriam longamente suas atividades: Rubén Rada, Gastón Ciarlo (Dino), Mateo, Horacio Buscaglis, Urbano Moraes, Chichito Cabral, Federico García Vigil (destacado também em sua atividade permanente na música "culta”); e, nos anos setenta: Totem, O Sindicato, Miguel e o Comitê, Psiglo, Montevidéu Blues etc. Depois um "lapso de silêncio" que logo começa a desaparecer com alguns cantores de raiz folclórica que aparecem e geram interesse, Carlos Benavides, Carlos Maria Fossatti, Los Eduardos, Tacuruses etc., em um tipo de música popular em escala planeária, graças aos meios massivos de comunicação ${ }^{10}$.

Procurando saber de que fontes se nutre a Música Popular e, mais especialmente, o Canto Popular, Washington Benavídez nos diz que ela "tem suas origens naturais no folclore, no saber popular de remotas raízes; confluem em nós três raízes de maior ou menor prevalência: a indo-americana, a africana e a européia"11.

8. DE ALENCAR PINTO,

G. Razones locas: e paso de Eduardo Mateo por la música uruguaya (Razões loucas: a passagem de Eduardo Mateo pela música uruguaia). Montevideo: Uruguay, 2005.

9. BONALDI, J. Canto popular uruguayo (Canto popular uruguaio). I, 1, 11, p. 130,1983

10. BENAVÍDEZ, W. Canto popular uruguayo (Canto popular uruguaio), I, 1, 9, p. $25,1983$.

11. Ibid. 
comunicação \& educação • Ano XIII • Número 3 • set/dez 2008

Roy Berocay nos dá sua visão sobre o movimento do Canto Popular:

Trata-se de um período particularmente interessante da música nacional que serviu também como matriz de alguns fenômenos que aconteceram posteriormente, fosse para dar-lhe continuidade, fosse para reagir a ele. Surgido paulatina e quase clandestinamente, o Canto Popular teve, antes de tudo, um objetivo mais político que artístico. Tratava-se de ganhar espaços contra a ditadura militar, que detinha o poder desde 1973. Assim, com a desculpa da realização de eventos musicais e artísticos, as pessoas encontraram no Canto Popular um modo de poder se reunir de forma coletiva (e legal) e expressar de maneira tangencial a princípio, e depois cada vez mais frontalmente, sua oposição a um governo que atentava contra o sentimento nacional. Com raízes no folclore herdadas dos músicos anteriores à ditadura (Daniel Viglietti, Alfredo Zitarrosa, Los Olimareños, para citar alguns exilados por razões políticas), uma nova geração surgiu, decidida a ocupar espaços [...]. Tratava-se então, claramente, de um movimento com uma finalidade específica, e ao mesmo tempo, em muitos casos, com uma visão bem fechada e politizada da música. Todo aquele que não se enquadrasse nos estilos vigentes ou com as formas habituais de interpretar ficava não somente malvisto, mas também questionado [...]. Eduardo Mateo, hoje considerado em muitos aspectos um dos pais da música popular uruguaia moderna, foi julgado em parte desse período como um louco delirante e costumava ser deixado de lado nos muitos eventos do Canto Popular ${ }^{12}$.

Ainda em busca de referências de outras fontes sobre música popular uruguaia, em Capagorry encontramos:

Eles prepararam, de alguma forma, o reencontro do canto popular e seu povo, fatos que a história imediata reconhece nos espetáculos de "La Cava" (Grupo Universo, Los Benavides, Los Eduardos, Omar Romano, Santiago Chalar, Abel García etc.) e nos shows de "Os que iam cantando" (Da Silveira, Trocón, Lazaroff, Di Pólito, Bonaldi), desde o "Shakespeare and Company", ou o Teatro Circular, ou a Aliança Francesa, todos eles acontecendo a partir do ano de 1977 em Montevidéu ${ }^{13}$.

de Democracia, Uruguay: 1985-2005 (Vinte anos de democracia, Uruguai: 1985-2005). Montevideo: Uruguay, 2005. p. 493-494.

13. CAPAGORRY, J. y RODRÍGUEZ BARILARI E. Aquí se canta: música popular (Aqui se canta: música popular). Montevideo: Arca, 1980. p. 30.

14. DE ALENCAR PINTO, op. cit., p. 77.

15. MUÑOS, C. y CASTILLO, R. El Uruguay de nuestro tiempo: las artes del espectáculo - 19581973. Génesis de la música popular Uruguaya $(\mathrm{O}$ Uruguai de nosso tempo: as artes do espetáculo - 1958-1973. Gênese da música popular uruguaia). Montevideo: Uruguay, 1986. p. 11-15.

E, segundo Darnauchans:

Sob o domínio do "Canto Popular" reúne-se, a partir da segunda metade da década de setenta, uma ampla gama de formulações e propostas, que vão daquelas menos ortodoxas, sobreviventes do finado rock compatriota, até as provenientes de cantores vinculados aos artistas mais tradicionais do folclórico, passando pelas "tanguices", a vertente latino-americanista e as inserções no popular da música contemporânea ${ }^{14}$.

Para Carlos Muñoz e Rubén Castillo, “Não há nenhum mistério no chamado Canto Popular ou Música Popular Uruguaia'. Esta é uma afirmação e uma resposta cultural e social. Música Popular Uruguaia (MPU) é um título mais abrangente apesar de ser de uso menos corrente" ${ }^{15}$. E prossegue mais adiante:

Desde Bartolomé Hidalgo até hoje - para tomarmos duas épocas tão distantes -, o processo é um só, a corrente musical variada, enriquecida, anônima muitas vezes e esquecida pelos estudos outras tantas vezes [...]. Mas há alguns nomes que marcarão os anos 60, "cantando com fundamento": Alfredo Zitarrosa (1936), uma 
personalidade distante e ao mesmo tempo carismática, e a canção de raízes rurais com a pintura de personagens e ambientes urbanos, muitas vezes de bairro ${ }^{16}$.

Continua a publicação, nomeando fortes referências da música uruguaia, e aparece a menção a

Eduardo Mateo, a quem todos conhecem como o precursor, mestre vivo, criador de El Kinto [...] muitas vozes e instrumentos não permaneceram calados durantes os anos mais difíceis, driblando mil problemas e contratempos, suportando proibições injustas [...]. Tenhamos então a grandeza de reconhecer seu valor e a importância de sua continuidade, apesar de todos os pesares. Fato que permitiu unir - por momentos com um fio fino, porém forte - as origens com o boom dos anos 60 e o leito enriquecedor da produção atual. Realidade que se fortaleceu no fim dos anos 70 e no próprio começo da década de $80^{17}$.

Segundo Carlos A. Martins: “[...] no começo dos anos 70, a Música Popular Uruguaia era um fenômeno vivo, desenvolvido, inquieto, contestador em forma e/ou conteúdo, em conteúdo e/ou relação [...]"18; e na página 30, ao referir-se à nova geração de autores e intérpretes do Canto Popular, lemos:

Houve também uma continuidade estética ou, ao menos, do que poderíamos chamar "atitude estética". O que significa dizer que, entre 1973 e 1982, encontramos linhas criativas e interpretativas que já estavam prefiguradas por um ou outro dos participantes da etapa anterior. Se houve evolução, desenvolvimento e combinação de velhas e novas influências - "anteriores locais" -, maior experimentação, não foi a ponto de nos permitir falar de uma verdadeira "ruptura" estética no período considerado. Uma característica que é herdada tal e qual é a preocupação em incorporar ao repertório canções de outras comarcas latino-americanas ${ }^{19}$.

Diante da pergunta de Marcos Gabay a Eduardo Mateo sobre o que até agora vem se chamando Canto Popular, ele responde:

Bem, não resta a menor dúvida de que é um movimento que deu e está dando um grande impulso à nossa música. É muito importante ir ao encontro do que é nosso. Tudo tem o seu lugar e seu estilo, e, se existe, é porque tem respaldo, e esse respaldo é porque há gente a favor. E é preciso entender as pessoas e ponto final. Você me entende? O Sabalero, Zitarrosa, Los Olimareños, ganharam uma força bárbara! Você percebe que falamos de La Claraboya? Você acha que existe alguma coisa ali que não seja o Canto Popular? Bom, o que acontece é que antes o movimento do CP não existia, mas existia Zitarrosa, Camerana, Discódromo etc. E então, quando o CP se forma, a metade das pessoas estava fora, com problemas. E agora estão voltando. Gabay: - Você não acha que, por que escuta "a última moda”, despreza o sujeito que canta uma milonga ou uma chamarrita? Mateo: - Como não? O que essa gente não vê é que toda música tem o mesmo material. Você não sabe o que é compor uma chamarrita! É dificílimo! A milonga também, o tango! Nossa! O que mais importa é a honestidade e a sinceridade ${ }^{20}$.

Por outro lado, opina Zitarrosa sobre o papel do cantor popular:

Um cantor popular deve ser necessário para sua gente; não um artista que pode ser substituído por outro similar; isto não quer dizer que ele não possa coexistir com outros artistas do povo, mas representa uma variedade particular da vida
16. Ibid.

17. Ibid.

18. MARTINS, C. Música popular uruguaya, 19731982: un fenómeno de comunicación alternativa (Música popular uruguaia, 1973-1982: um fenômeno de comunicação alternativa). Montevideo: Uruguay, 1985. p. 25-30.

19. Ibid., p. 30.

20. DE ALENCAR PINTO, op. cit., p. 240. 
comunicação \& educação • Ano XIII • Número 3 • set/dez 2008

21. PELLEGRINO， G. Cantares del alma, bibliografía definitiva de Zitarrosa (Cantares da alma, bibliografia definitiva de Zitarrosa). Montevideo: Uruguay, 1999. p. 173.

22. Ibid.

23. CAPAGORRY y RODRÍGUEZ BARILARI, op. cit., p. 9.

24. CURTIUS, Ernst R. La literatura europea y Edad Media latina (A literatura européia e Idade Média latina). Madrid: Gredos, 1976. p. 216. [Ed. bras. A literatura européia e Idade Média latina. Tradução de Paulo Rónai e Teodoro Cabral. São Paulo, Hucitec/Edusp, 1996.] sentimental do povo, um aspecto único e diverso dessa imensa vida múltipla; é um produto cultural do povo, que representa menos cabalmente os seus, segundo seja mais ou menos artista no sentido estrito da palavra ${ }^{21}$.

E diante da solicitação de definir a missão do cantor, encontramos:

Um artista é um criador, um artesão, mas o artista, o cantor popular, o trovador trabalha com o material menos nobre e ao mesmo tempo mais precioso: a palavra falada de uso cotidiano, as variantes melódicas já cunhadas na alma das pessoas por acumulação sucessiva, os sentimentos mais universais e a lógica do puro senso comum; se com esse material ele conseguir uma obra perdurável, ele merece ser qualificado como cantor popular ${ }^{22}$.

O tema da identidade e seus cultivadores na música conduziram a uma busca de raízes, na qual se uniram poesia e música popular, e levaram Juan Capagorry e Elbio Rodríguez Barilari a expressar:

Quase todas as figuras importantes da literatura uruguaia contemporânea estão representadas no cancioneiro popular: Liber Falco, Idea Vilariño, Ida Vitale, Amanda Berenguer, Circe Maia, Washington Benavídez e Carlos Maggi são alguns dos mais conhecidos. Pessoas de gerações posteriores foram se integrando à lista, estando os mais freqüentados entre os montevideanos: Enrique Estrázulas e Victor Cunha. A poesia gauchesca e mais genericamente os poetas de inspiração do campo tiveram sempre uma relação direta com a música. A nomes como os de Wenceslao Varela, Romildo Risso e, inclusive, Osiris Rodríguez Castillo podem ser acrescentados ainda os de Victor Lima, Ruben Lena e Lucio Muniz, entre outros ${ }^{23}$.

\section{TEMÁTICA}

A temática escolhida pelos cantores populares foi ampla, diversa, até na forma de tratar da política, que os obrigou a serem bastante cuidadosos para evitar a censura, ou coisas piores, e estabeleceu com seu público um forte vínculo, o qual, muitas vezes adivinhava nas entrelinhas ou completava com sua imaginação o que o autor não havia podido expressar; colocava, então, um sentido naquelas letras que, de repente, tinham sido criadas sem finalidade política expressa, fechando assim, contra todas as previsões anteriores, o ciclo do ato criador da comunicação. Os temas escolhidos diziam respeito, muitas vezes, ao amor, a coisas profundas ou simples, e, de alguma forma, muitos dos cantores identificaram-se com a figura do Trovador, traço que vários deles traziam explicitamente em suas canções. Interessa aqui resgatar as palavras de Ernst R. Curtius:

O chamado sistema de virtudes do cavaleiro provavelmente não foi tal sistema; contém categorias ético-estéticas de tipo laico que em parte já estavam constituídas muito antes de que surgisse a cavalaria: a fidelidade do vassalo, a alegria e outras criações do amor cortês, que no sul da França já existiam em torno do ano $1100^{24}$.

No meu entender, a identificação do cantor popular, ou de muitos deles, com a figura do trovador passa pela fidelidade do vassalo a quem ele considera 
merecedor de sua vassalagem, ou seja, o público (em contraposição à vassalagem clássica, prestada ao senhor feudal), esse povo que se nutre e a ele retorna com suas criações, com seus bens simbólicos; e, ao fazê-lo, outorga fermentável importância à transmissão de valores e identidade em forma oral e em um exercício de real comunicação com o público que o entende, o conhece e se identifica com suas canções.

Lendo Mónica Salinas, encontramos uma citação de W. Benavídez, para quem "equiparar o cancioneiro popular uruguaio com as criações de poetas, jograis e trovadores medievais implica reconhecer naquele o brilho da alta poesia que ilumina a antiga literatura medieval"25; e mais adiante, encontramos:

[...] a palavra "trovador" se refere a um gênero de artista ligado a um contexto histórico preciso. Provém do occitano antigo "trovar", que significa encontrar. O que o trovador, nascido no medievo, encontrava ou descobria era uma nova forma de expressar temas eternos e universais, e ritmos que realçam a beleza de seu dizer ${ }^{26}$.

E justamente esse exercício, que passa muitas vezes pelo artesanal ofício de procurar e "encontrar", é exercido plena e criativamente por Zitarrosa e Mateo. Ambos procurando, trovaram ou encontraram sua linguagem musical.

\section{ALFREDO ZITARROSA E EDUARDO MATEO (ALGUMAS CONCORDÂNCIAS)}

Interessa-nos lembrar que ambos pertenceram (Zitarrosa é quatro anos mais velho) a uma mesma geração: Alfredo Zitarrosa (1936-1989) e Eduardo Mateo (1940-1990) nasceram em Montevidéu, no hospital Pereira Rossell, eram de origem humilde e dotados de um espírito curioso, com raízes sonoras que se fincam no candombe; os dois escolheram o violão como instrumento ideal para sua música (no caso de Mateo, ele também tocava muito bem o tambor) e impuseram um estilo violonístico próprio, pessoal, intransferível. Quando compunham candombe, o faziam unindo o violão com o texto próprio; então, com eles se canta o candombe, e ambos possuem uma voz e um estilo originais.

Usavam para suas criações duas matérias-primas imprescindíveis: a palavra e o som, e com elas elaboravam uma linguagem particular que, ao longo de seu trabalho artístico, foi se afirmando. Com amplos interesses em temas tão intrinsecamente humanos como a vida, o amor, a tristeza e a morte, transformaram-se em "esponjas", recolhendo e embebendo tudo o que os rodeava. Cultivaram, assim, ao longo de sua existência, uma grande sensibilidade e uma visão interior que plasmaram em sua obra artística, na qual se unem música e poesia.

São ambos altos expoentes da criatividade, possuidores de complexos mundos, nos quais a experiência subjetiva é povoada de pensamentos e imagens que procuram ser expressos. Os dois incursionam em territórios novos, não explorados musicalmente, onde procuram e encontram soluções não-convencionais
25. SALINAS, M. Poesía y mito: Alfredo Zitarrosa (Poesia e Mito: Alfredo Zitarrosa). Montevideo: Uruguay, 2006. p. 16-58.

26. Ibid. 


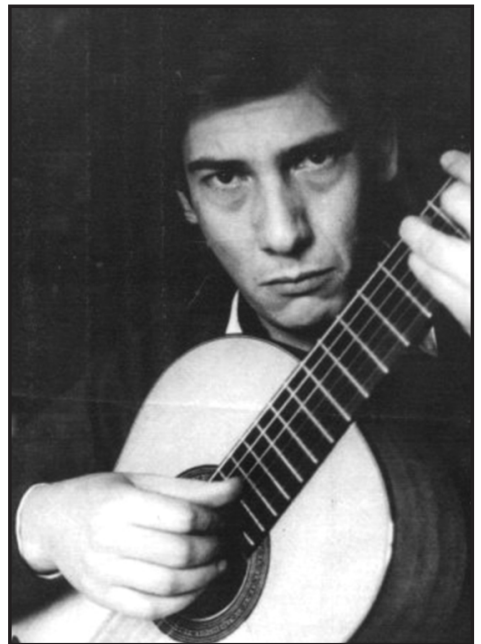

Zitarrosa - 1936-198927. e, portanto, compartilham a rebeldia inerente ao ato criativo. Por tudo isso, atualmente são reconhecidos como espelhos que refletem boa parte da identidade musical do Uruguai.

E aqui parecem terminar as semelhanças, já que Alfredo Zitarrosa optou por ser cantor popular, com boa parte de sua obra a serviço de um forte compromisso social e político. Em sua música está presente grande parcela da vida que passou no interior, na zona rural, a ponto de essas vivências exercerem influência marcante em sua obra. Viajou para a Argentina e Peru, onde, em 1963, começou seu trabalho como cantor, através de um programa de televisão em Lima. Passou pela Bolívia e, ao regressar ao Uruguai, continuou sua atividade como cantor, autor e intérprete. Em 1964, estreou como cantor profissional, na Rádio Difusora de SODRE, ofício ao qual dedicou maior energia criativa até o final de sua vida, da qual também dão prova seus trabalhos como jornalista no Uruguai e no estrangeiro.

Já Mateo permaneceu a maior parte da vida em Montevidéu, onde desenvolveu sua obra. Empreendeu uma busca criativa em um sentido diferente daquele tomado por Zitarrosa; após uma viagem ao Brasil, retornou enriquecido com o aporte de João Gilberto, que, por sua vez, exerce uma forte influência sobre Caetano (o qual o reconhece como pioneiro), que, graças a esta influência, vai fundar, com outros músicos, o Tropicalismo, movimento-chave da Música Popular Brasileira. Mas diferentemente de Caetano Veloso, Mateo vê ali a influência dos Beatles, e é possivelmente através deles que toma conhecimento da música de Ravi Shankar e as criações musicais da Índia, que ele pesquisa, aprendendo-a e incorporando-a, a ponto de tocar o violão como a tabla indiana, fato que põe em evidência sua capacidade transmutadora e criadora.

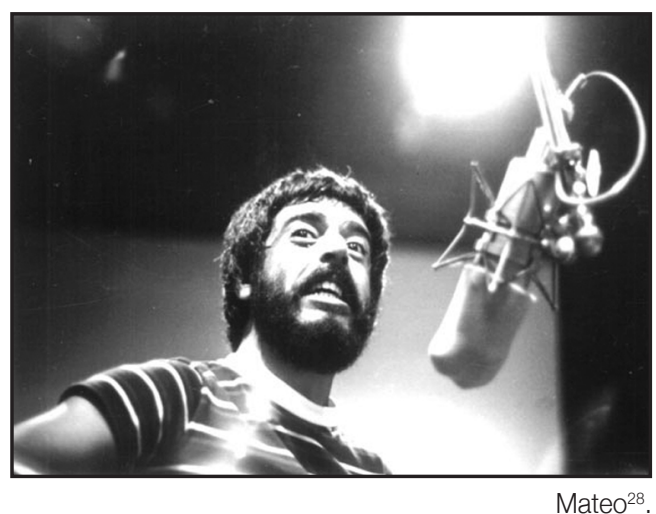

27. Disponível em: $<$ http://www.grumete. com.uy/ayuda/archivos/ AlfredoZitarrosa19361989.jpg>.

28. Disponível em: $<$ http://www.clubdeldisco.com/numerosanteriores/numero15.php>.

\section{ALFREDO ZITARROSA}

Zitarrosa reconhece em sua música as três vertentes às quais alude Benavides e, ao criar texto e melodia, designa e confere identidade não só a seu país, mas a toda a região, ampliando as fronteiras, a ponto de, uma noite, quando Borges ouve o poeta Juan Jones cantarolar Milonga para una niña, deter-se e exclamar: "Esse é o som, esse é o som da Pátria!". 
A milonga desempenha papel central em sua obra, a qual define como o blues do Sul; e no que se refere à milonga, o escritor Pellegrino recorda o que dizia Zitarrosa:

Há aqueles que sustentam que o tango paga tributo ao candombe, como também, e isto é assim e ninguém tem a menor dúvida, paga tributo à milonga que também é negra. O nosso paisano, o gaucho repentista, o jogral, o trovador camponês, canta por cifra; rasqueia o violão a golpes, entalha o verso com a mão. O negro é mais jocundo e trabalha com a mão uma milonga em arpejos, na qual encaixa as décimas. A milonga é negra, o candombe é negro e o tango provavelmente deve ser negro também ${ }^{29}$.

Ao criar, vincula-se profundamente com sua produção e, ao fazê-lo, prepara uma relação de diálogo entre os dois intrumentos centrais de usa obra, que são a música e a palavra; a ambas ele pesquisa, explora, pule em um exercício artesanal de ourives, que procura chegar - e consegue - na essência mais profunda da palavra e da música. Cuida e ama a palavra, e ao trabalhar com ela nasce o texto, a letra da canção que está, em primeiro lugar, a serviço da ética, reconhecendo o trabalho formador como o eixo principal do Ofício de Cantor, um artesanal ofício que coloca a serviço do povo.

\section{Zitarrosa: criador reflexivo}

Zitarrosa $^{30}$ deixou testemunho da profundidade de seu pensamento e de sua investigação criadora em vários jornais e publicações (é de se recordar seu trabalho como jornalista no Uruguai, no Peru, no México, entre outros), e muitas de suas reflexões sobre o ato de criar um bem simbólico, uma canção, são recolhidos em El oficio de cantor y canciones [O ofício de cantor e canções], em que nos conta as leituras que o influenciaram. Ao lê-lo, enfronhamo-nos na profundidade de seu trabalho criador, na pesquisa que realizou para concluir com exploração e criação o ato criativo:

Obviamente não conheço os segredos da criação poética, nem poderia dizer nada a respeito, exceto citar os grandes poetas que me serviram de alimento ao longo da vida, Vallejo, Machado, Pavese, Rilke, Octavio Paz; deveria falar por mim nesse momento, através de suas respectivas obras de ensaio ou inclusive através de seus poemas, onde uns e outros tentaram também racionalizar suas experiências. Com eles aprendi o pouco que sei [...]. Não obstante, comprovei pelos acontecimentos que a primeira aparição de uma canção tem uma clara fisionomia rítmica. Muitas vezes, nem sequer há palavras concretas dentro da frase-ritmo [...] no caso de uma canção terminada, o mais freqüente é que a música e as palavras tenham descartado uma em favor da outra, algumas de suas pretensões próprias. Afora o fato de eu não ser um poeta, em minhas canções, ao menos, isto ocorre quase sempre [...] o que para mim é a regra de ouro da criação: no percurso desta verdadeira elaboração consciente de uma canção, o compositor deve permitir-se dizer algo; a magia do som de um instrumento musical "pede" palavras aos gritos. Aquele que vai colocando as palavras deve deixar-se seduzir por essa exigência imediata; nada de escolher entre uma ou outra palavra, nesse momento preciso
29. DE ALENCAR PINTO, Razones locas, op. cit, p. 229.

30. SALINAS, op. cit., p. 46. 
nada de desentendimento, menos ainda se - depois da primeira palavra - vierem outras três que estão "confessando" algo, gemendo ou provocando, ou dizendo simplesmente um absurdo. Essas palavras iniciais constituem um andaime no qual a canção deverá se equilibrar sem vacilações qualquer que seja sua sorte ("Ya", 14 de julho de 1970) ${ }^{31}$.

Este artigo foi escrito no começo dos anos 1970, e com ele iluminam-se os segredos da persistente e árdua tarefa de se vincular com a palavra, o ritmo, o ritmo das palavras, o ritmo musical imbricados estreitamente:

Sempre, para um conceito qualquer, há uma expressão idiomática já consagrada pelo povo, mais ou menos folclórica, mais ou menos culta ou elusiva. Além disso, o verbo escolhido ao acaso entre aquelas motivações inconscientes que provocam sua "aparição" surpreendente, com permissão do ânimo - pois é preciso estar calmo -, se vem cheio de árvores e pássaros, também admite arbustos, arborescências, ar, vento, trinados e pios, tem dentro um movimento apaixonado, uma tendência que o inclina a certa região do sentimento, onde um "trinado" em tom menor pode ser saudade ao invés de alegria, onde um "pio" pode ser alegria ao invés de inocência, pode ser cômico ou enternecedor ${ }^{32}$.

\section{EDUARDO MATEO}

Das variadas estradas pelas quais transita a criação, diferente foi o caminho escolhido por Eduardo Mateo.

No seu trabalho criador, tão complexo, por momentos lúdico, por outros atormentado e tão semelhante em muitos aspectos à perseguição de Bird Parker, Mateo procura, como Bird, empurrar as fronteiras da música, em um trabalho que se assemelha ao de muitos artistas plásticos de finais do século XX e começo do XXI; da mesma maneira que Charlie Parker, tentou subverter a ordem estabelecida, atacando a tradição, e, como este, sua vida transcorreu por caminhos pouco convencionais, com incursões na marginalidade e na transgressão.

Ariel Ameijenda diz de Mateo:

Ele sempre perseguia isso que ele chamava de des-composição. Por exemplo, ele chamava de des-composição quando fazia um ritmo que ficava flutuando sobre um outro ritmo. Você percebe que às vezes ficava uma coisa super-simples, mas que a torcia, caía uma na terra, e a outra não. Você percebe estas coisas minimalistas?

- Descompassos.

ARIEL: - Ele se encantava com esses descompassos. Ele dizia que neles entrava tudo. Na des-composição, ele me dizia, entram todos os ritmos. Rompem-se por completo o modo, a escala, a harmonia, todas as notas são válidas. Sempre que tocávamos aqui, tentávamos chegar a isso. Começávamos a tocar um pouco, e depois de uma meia hora começávamos a entrar nisso que ele chamava de descomposição, e nesse estado ficávamos horas, sem nos cansarmos. Saíram coisas maravilhosas nessa época. Tocávamos "blues hindus". Eu chegava a momentos de êxtase, entende? Que perdíamos a noção do tempo. Cheguei a um fluir que não 
consegui com ninguém, salvo o que estou conseguindo agora, depois de anos de meditação, com o tocador de tabla com quem toco, de chegar a um momento em que você não pensa mais no que sai, você não processa, e tudo entra, tudo sai bem.

- Ele tocava a percussão e você a cítara?

ARIEL: - Ele tocava tabla e, às vezes, violão ${ }^{33}$.

Eduardo Mateo, no ato da criação, fazia uso completo da liberdade; ele era o alma mater de "El Kinto" e pioneiro ao criar o Candombe-beat, novo gênero no qual se amalgamam o candombe montevideano e a música beat estrangeira. E em outra manifestação de talento criativo, aparece em suas letras o uso do castelhano, em uma época em que os que faziam música beat cantavam em inglês. Com esse trabalho pioneiro, reconhecia e imprimia em sua música uma forte marca de identidade, identidade que em seu momento não foi compreendida ou sofreu resistência por ser considerada música pertencente aos que viviam em determinado bairro (Pocitos ou Carrasco), em determinada classe social e desinteressados de todo compromisso político. Ao criar o candombe-beat, e reconhecer ou incorporar o candombe em sua música, assemelha-se à inovação musical que realiza Carlos Santana ao incluir em sua música - o rock - o ritmo latino, trabalho que Mateo fez no Uruguai muitos anos antes.

Com a palavra sua relação era, sobretudo, lúdica; para ilustrar isto, há no livro Razões Loucas [Razones Locas] um diálogo entre Jaime Roos e Mateo:

JAIME ROOS: - Escute uma coisa: eu vi que você usa um verbo, "arece”, em certo momento em uma de suas músicas. Então é um verbo que vem de ar, não?

MATEO: - É.

JAIME: - Não existe o verbo ar, você inventou.

MATEO: - Eu invento.

JAIME: - E há um conto de Borges em que fala de um idioma no qual não se fala nada mais que com verbos. Por exemplo, ao invés de dizer "apareceu a lua", se diz: "luneia".

MATEO: - E não tem outro remédio. Se tem que inventar, inventa-se ${ }^{34}$.

Essa capacidade de entrar no território do jogo, onde seu espírito criador sentia-se mais cômodo, aplica-se também à sua voz; com ela cantava, jogava, grunhia, murmurava, resmungava, inventava onomatopéias, usava-as assemelhando-as a outro instrumento. Algumas vezes cantava como um garrafeiro - daqueles que se escutam em Montevidéu - e, ao juntar à sua música o som da rua, o som de todos os dias, os termos cotidianos, as gírias, fazia uso de sua captação do meio, o qual reconhecia, assimilava e transformava, incorporando os signos sonoros que possuía à linguagem popular, e nessa tarefa é pioneiro, marcando um rumo, dando um testemunho de criatividade e identidade.

33. DE ALENCAR PINTO, op. cit., p. 340-341.

34. Ibid., p. 295. 
comunicação \& educação • Ano XIII • Número 3 • set/dez 2008

Com respeito às musicações, leiamos o que diz Buscaglia:

Quando nos propusemos a fazer as Musicações, quando colocamos como norma das musicações que tudo fosse em castelhano, que houvesse candombe, que as pessoas participassem, que isso significava uma recuperação de coisas nossas e latino-americanas, enfim. Havia uma cabeça política, e Mateo tinha esta cabeça e eu, nesta altura, também já tinha bastante [...]. De repente, não foi planejado a partir daí, mas a partir da vontade, da raiva de não poder mostrar o que fazíamos, da raiva de escutar no rádio todas as porcarias portenhas que vinham, a raiva de ver gente uruguaia cantando em inglês e tentando imitar os portenhos. E nós entramos naquilo que entendíamos que tínhamos que fazer. Tem toda uma geração que viveu as Musicações, e eu encontro esta gente pela rua e essa é uma de suas melhores lembranças ${ }^{35}$.

Diante do aparente desinteresse de Mateo por implicar-se pessoalmente e com sua obra no meio político, é importante nos determos na opinião de Guilherme de Alencar Pinto, que, diante da necessidade de resumir de maneira bem sintética o aspecto da obra de Eduardo Mateo, diz:

[...] não é uma música quietista, já que tem uma concepção bastante original em todos os seus parâmetros, e freqüentemente pode servir, através da surpresa e da estranheza, para "escavar" ou "deslocar" o ouvinte. Consolida a identidade cultural da qual surge porque usa com freqüência elementos musicais específicos de sua região cultural, como o ritmo de seu candombe e os ares de milonga e eventualmente os conjuntos de rua e o tango; e adota firmemente o castelhano ${ }^{36}$.

Hoje, boa parte do público mudou sua atitude em relação à obra de Mateo. Escreve-se sobre ele, seus trabalhos foram reeditados em CD, existe uma praça que foi batizada com seu nome e está em vias de se constituir uma associação para a difusão, estudo, proteção e pesquisa de sua obra. Os jovens o escutam e alguns batizam seus filhos com o nome de Mateo como forma de homenageá-lo. Alguns militantes que não apreciavam seu trabalho, encontram aí o testemunho de uma época e vão mudando a visão sobre a música e os temas de suas canções. Há muito tempo continuam nos surpreendendo sua contribuição inovadora e a riqueza de sua música, e escutá-la nos permite enriquecer e ampliar o complexo tecido da música urbana uruguaia.

\section{A CRIAÇÃO DE ZITARROSA E MATEO E SUA CONTRIBUIÇÃO A PARTIR DA IDENTIDADE E DA CRIATIVIDADE}

35. Ibid., p. 339. 36. Ibid., p. 140.
Entre Zitarrosa e Mateo, há uma grande distância. Hoje, quando nenhum dos dois mais está presente fisicamente, permanece sua música, suas canções são ouvidas, queridas e reconhecidas e atuam como ponte sonora entre gerações.

Entre a canção urbana - montevideana mais precisamente - e a canção que finca suas raízes na música folclórica, na música de "terra adentro", da fusão de 
ambas as músicas com outras forâneas, procria-se, nasce e cresce, pelas mãos do músico, uma criação sonora própria, nossa, que se nutriu de outras identidades musicais para "apreendê-las" e elaborar um complexo universo musical nosso, próprio, adulto, fruto de criadores maduros.

A criação contém em si não só conceitos racionais, mas fundamentalmente sentimentos, emoções, em que o artista expressa, com sua obra, com sua poesia, com seu canto, o sentimento que capta em seu entorno, em sua gente. Desse processo de captação, elabora uma canção, uma poesia, uma música, as quais, ao retornarem para o público, ao serem ouvidas, ao serem cantadas, atuam como ponte, afiançando o vínculo do artista com o público. Nesse vínculo entre cantor, poeta e público, a relação opera principalmente através do sensível, e é o espectador quem outorga, completa e confere sentido à produção artística, à música, à canção.

\section{CRIATIVIDADE VERSUS CLIMA POLÍTICO}

Fica colocada a grande interrogação: Como foi possível, nas duras condições imperantes durante os anos de 1973 a 1985, a aparição de um importantíssimo movimento artístico como o do Canto Popular (no Uruguai e por autores que estavam no exílio e fora dele), quando as condições externas eram tão adversas? Segundo Guilford, há determinadas condições para o desdobramento das forças criativas, a saber:

1. Ausência de egoísmos.

2. Ausência de conflitos, angústias e obsessões.

3. Ausência de estresse.

4. Necessidade de ascetismo informativo.

5. Necessidade do diálogo e do contato grupal.

6. Identificação com o objeto.

7. Integração do pensamento convergente com o divergente ${ }^{37}$.

Algumas das condições anteriores são internas, próprias de cada indivíduo, mas o surpreendente é como o fenômeno da criatividade atuou em um meio no qual reinava um sentimento geral de angústia provocada pela situação pessoal e social, plena de conflitos pessoais, humanos, sociais, políticos, com a ameaça diária de detenção, prisão, tortura, desaparecimento, exílio, quando o jornal era gerador de inquietação e estresse, quando a informação era escassa, os meios de comunicação eram os do governo e o diálogo dava-se com os muito próximos ou familiares e amigos; bem, quando todas as condições externas eram adversas, surge um dos movimentos mais ricos, criativos e inovadores, um movimento pleno de transgressão e rebeldia, no qual se refletia inequivocamente o sentir de muitos uruguaios, e ao fazê-lo lança profundas raízes na árvore da identidade nacional, identidade da qual, sem dúvida, esse movimento é um de seus progenitores - fazendo uso do original significado da palavra liberdade.
37. LESPADA J. C. Aprender haciendo (Aprender fazendo). Buenos Aires: Humanitas, 1989. p. 67. 
comunicação \& educação • Ano XIII • Número 3 • set/dez 2008

\section{IDENTIDADE E CRIATIVIDADE}

Sobre o tema Identidade e criatividade é oportuno citar Coriún Aharonián, em sua conferência sobre A criatividade como possibilidade e como necessidade absoluta, proferida na abertura do Segundo Encontro de Educação pela Arte, organizado pelo Instituto Uruguaio de Educação pela Arte e pela Arte Oficina Barradas, que aconteceu em outubro de 1999, na cidade de Montevidéu, diante de um público formado por artistas, músicos, educadores pela arte, docentes etc. Encontro no qual o eixo central era a identidade, Aharonián - falando desse tema que hoje está em voga, em pleno fenômeno de globalização - opina:

A defesa dos fatores de identidade, portanto, é hoje um desafio maior do que há meio século. E os educadores têm uma responsabilidade tão grande como os artistas criadores. Apenas aprovando o criativamente livre e apoiando-se nisso, poderá o educador dar uma resposta à ação depredadora das transnacionais e de seus servidores locais, isto é, a maior parte dos meios de cada país do sistema colonial $^{38}$.

Mais adiante recomenda: "Nossa tarefa central como educadores deveria ser potencializar cada homem como indivíduo. Uma sociedade de homens livres é uma sociedade de indivíduos. O homem-massa não é um indivíduo. É um buraco negro da condição humana” ${ }^{39}$.

\section{SÉCULO XX! SOB UM MESMO CÉU}

Sob este céu, o mesmo que inaugurou profeticamente Hidalgo, este céu de luta pela liberdade - uma liberdade individual, mas com direito de uso e gozo por todos, liberdade para a qual contribuíram nossos artistas, ao criar com a melhor arma, a arma da liberdade criadora -, e sob o qual transcorrem nossos dias, sinto que é o momento adequado para dizer a nossos Músicos Populares obrigada pela luta por nossos direitos; obrigada por contribuir para a formação e o afiançamento de nossa identidade; obrigada pelo ritmo - que pôs calor e cor sob o céu cinza; obrigada pela música plenamente uruguaia; obrigada pela resistência cultural e pela liberdade; obrigada pelo uso da melhor arma/ferramenta do ser humano: a criação.

\section{REFERÊNCIAS BIBLIOGRÁFICAS}

AHARONIÁN, C. Educación, arte, música (Educação, arte, música). Montevideo: Uruguay, 2004.

BALZO, H. La vida musical (A vida musical). Montevideo: Uruguay, 1969.

38. AHARONIÁN, C. Educación, arte, música (Educação, arte, música). Montevideo: Uruguay, 2004. p. 14.

39. Ibid.
BENAVÍDEZ, W. Canto popular uruguayo (Canto popular uruguaio). I, 1, 9, 1983.

BEROCAY, R. 20 años de Democracia, Uruguay: 1985-2005 (Vinte anos de democracia, Uruguai: 1985-2005). Montevideo:Uruguay, 2005.

BONALDI, J. Canto popular uruguayo (Canto popular uruguaio). I, 1, 11, 1983. 
CAPAGORRY, J. y RODRÍGUEZ BARILARI, E. Aquí se canta: música popular (Aqui se canta: música popular). Montevideo: Arca, 1980.

CURTIUS, Ernst R. La literatura europea y Edad Media latina. Madrid: Gredos, 1976. [Ed. bras.: A literatura européia e Idade Média latina. Tradução de Paulo Rónai e Teodoro Cabral. São Paulo, Hucitec/Edusp, 1996.]

DE ALENCAR PINTO, G. Razones locas: el paso de Eduardo Mateo por la música uruguaya (Razões loucas: a passagem de Eduardo Mateo pela música uruguaia). Montevideo: Uruguay, 2005.

GARCÍA CANCLINI, N. Culturas híbridas: estrategias para entrar y salir de la modernidad. Buenos Aires: Paidós, 2005. [Ed. bras.: Culturas híbridas: estratégias para entrar e sair da modernidade. Tradução de Heloísa Pezza Cintrão e Ana Regina Lessa. 3. ed. São Paulo: Edusp, 2000.]

HIDALGO, B. Cielitos y diálogos patrióticos (Cielitos e diálogos patrióticos). Montevideo: Uruguay, 1969.

LESPADA, J. C. Aprender haciendo (Aprender fazendo). Buenos Aires: Humanitas, 1989.

MARTINS, C. Música popular uruguaya, 1973-1982: un fenómeno de comunicación alternativa (Música popular uruguaia, 1973-1982: um fenômeno de comunicação alternativa). Montevideo: Uruguay, 1985.

MUÑOS, C. y CASTILLO, R. El Uruguay de nuestro tiempo: las artes del espectáculo - 1958-1973. Génesis de la música popular uruguaya (O Uruguai de nosso tempo: as artes do espetáculo - 1958-1973. Gênese da música popular uruguaia). Montevideo: Uruguay, 1986.

PELLEGRINO, G. Cantares del Alma: bibliografía definitiva de Zitarrosa (Cantares da alma: bibliografia definitiva de Zitarrosa). Montevideo: Uruguay, 1999.

SALINAS, M. Poesía y mito: Alfredo Zitarrosa (Poesia e mito: Alfredo Zitarrosa). Montevideo: Uruguay, 2006.

VIDART, D. La trama de la identidad nacional (A trama da identidade nacional). Montevideo: Uruguay, 1997.

WEROSCH, Sheila y VENEZIANI, W. Abran cancha, acá baila un oriental (Abram caminho, aqui está dançando um uruguaio). Montevideo: Uruguay, 2006.

ZITARROSA, A. El oficio de cantar y canciones ( $O$ ofício de cantar e canções). Montevideo: Uruguay, 2001.

\section{Endereço eletrônico}

$<$ http://letras-uruguay.espaciolatino.com/ayestaran/la_cifra.htm>. 